\title{
Revisão de artigios científicos: privilégio para poucos; benefício para todos
}

\author{
Cristina Muccioli, Mauro Campos, Mauro Goldchmit, Paulo E. Correa Dantas, Samir J. Bechara, Vital Paulino Costa
}

Recentemente alçada a um patamar cientificamente mais elevado com a obtenção da tão sonhada indexação em bases de dados internacionais como o PUBMED/MEDLINE e a EMBASE/EXCERPTA MEDICA, além da valiosa indexação na SciElo (Scientific Electronic Library) e na LILACS, nossa revista científica, os Arquivos Brasileiros de Oftalmologia, personalizada por seu Editor Chefe e seus Editores Associados, buscam continuadamente aperfeiçoar os mecanismos de submissão, avaliação e publicação de artigos científicos.

$\mathrm{O}$ processo de gerenciamento de artigos científicos, ao que possa parecer simples à primeira vista, envolve-se de múltiplas e interdependentes fases que culminam com a publicação da revista científica formatada, tal qual a recebemos em nossas casas e consultórios. Olhando-a pronta e (justiça seja feita!) bem acabada, nem passa pela cabeça do leitor ou até mesmo do autor, a via sacra pela qual passa a construção dessa fonte fenomenal de informações científicas.

Dentre todas as etapas deste difícil processo, consideramos, unanimemente, como a mais crítica, a da revisão. E não são poucas as razões para isso.

As dificuldades começam com a atribuição de revisores a determinados trabalhos; ou seja, determinar para aquele específico assunto, de uma até três pessoas que demonstrem ter espírito crítico, reputação e cabedal científico para tal tarefa, além do julgamento de seu desempenho histórico como autor, revisor e pesquisador. Tudo isso sem se descuidar de possíveis conflitos de interesse ou disputas prévias que possam existir. Em nosso caso, a escolha do revisor no sistema de revisão por pares (peer review) é auxiliada por uma base de dados de revisores pré-selecionados por área temática e expertise.

Não importa quão rápido os artigos científicos possam ser trocados entre autores, editores e revisores com a introdução de ferramentas modernas como nosso processo de gerenciamento eletrônico de artigos científicos, o ABOONLINE. Nosso calcanhar de Aquiles continua sendo o atraso no retorno de revisões de qualidade.

Acabamos, num processo que se auto-alimenta, retardando a decisão de aprovação ou não da publicação do artigo, o que pode afetar a reputação de nossa publicação junto à comunidade científica e junto aos órgãos de indexação como o PubMed e EMBASE.

Certamente, uma revisão rápida e de alta qualidade é o elemento mais desejado do processo de revisão de artigos científicos. Entretanto, rapidez na revisão sem a acurada crítica judiciosa e questionamentos pertinentes, dificultam a seleção de artigos científicos meritórios.

Desse modo, gostaríamos de ecoar os ensinamentos do Prof. Saul Goldenberg, mestre de tantos nas artes e agruras da editoração de revistas científicas, em seu artigo sobre "Publicação do trabalho científico: compromisso ético". Quando cita as responsabilidades do revisor:

- Uma revisão crítica e justa é parte essencial do processo de publicação;

- Cada membro da comunidade científica tem a obrigação de assessorar as revistas no processo de revisão por pares;

- Espera-se do revisor, avaliação científica e literária experiente, crítica e sem preconceitos de relatos científicos na sua área de conhecimento e habilidade;

- Devolver os pareceres prontamente dentro do prazo concedido pelos Editores;

- O revisor não deve aceitar avaliar o artigo científico se:

- Não se sentir competente para apreciar a pesquisa ou os itens levantados;

- Existir conflito de interesse ou que um relacionamento pessoal com o(s) autor(es) que possa prejudicar o julgamento de artigo científico;

- O revisor deve manter a confidencialidade dos dados do estudo;

- O revisor deve apoiar sua análise crítica em referências adequadas. Qualquer semelhança considerável com trabalho já publicado deve ser comunicada ao Editor;

- O revisor deve identificar casos de citação inadequada ou omitida de trabalho importante de outra;

- Basear sempre sua decisão de aprovar para publicação em avaliação objetiva da qualidade científica e literária do manuscrito.

Esperamos contar sempre com o inestimável apoio e o trabalho fundamental de nossos revisores para continuarmos nossa caminhada e missão de divulgar o melhor da atividade científica nacional para o mundo.

\section{REFERÊNCIA}

1. Goldenberg S. Publicação do trabalho científico: compromisso ético. São Paulo; 2001. Disponível na URL http://www.metodologia.org. 